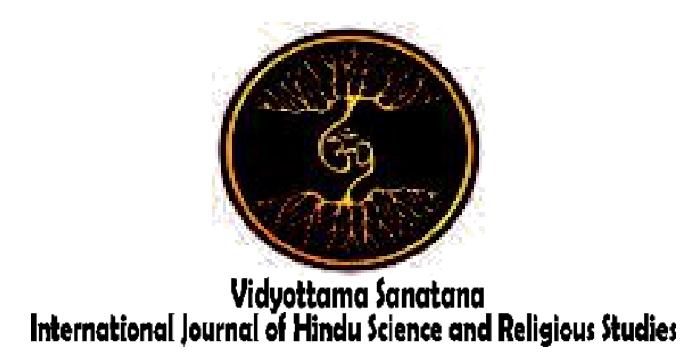

Vol. V No. 1 June 2021

\title{
RELIGIOUS MODERATION IN GEGURITAN NENGAH JIMBARAN
}

\author{
By: \\ Krisna S. Yogiswari ${ }^{1}$, Ni Made Ari Dwijayanthi ${ }^{2}$ \\ Sekolah Tinggi Agama Hindu Negeri Mpu Kuturan Singaraja \\ Email: yogiswarikrisna@gmail.com
}

Received: January 19, 2021

Accepted: June 30, 2021

Published: June 30, 2021

\begin{abstract}
Geguritan Nengah Jimbaran as a material object in this study is a traditional Balinese literary work written by Cokorda Mantuk Ring Rana. This study uses a qualitative approach that focuses on finding the meanings of religious moderation in the Geguritan Nengah Jimbaran text. The hermeneutic method is applied to understand and interpret the meaning and intention of Cokorda Mantuk Ring Rana in his writing. Based on the analysis carried out at Geguritan Nengah Jimbaran, it shows Balinese people are indeed dominated by Hindus but they have a great tolerance and can live harmoniously side by side among different faith during the reign of Cokorda Mantuk Ring Rana. It can be concluded that religious tolerance as one of the spirits of religious moderation has long been present and has become a habit of Balinese people today.
\end{abstract}

Keywords: religious moderation, tolerance, Geguritan Nengah Jimbaran

\section{INTRODUCTION}

The starting point for the culture emergence comes from shared knowledge that is disseminated socially and evenly. In culture, there is the main entity; namely the individual and society. Communication plays an important role as a medium for social processes between individuals and society. Meanwhile, culture persists or is taught from generation to generation based on the principle of reciprocity that is the existence of closeness and reciprocity relationship. This is similar to what is said by Permanadeli (2015: 22) that social representation is rooted in the movement of forming knowledge that comes from individuals and society as two interconnected entities and collectively creates patterns and rhythms that are their own unique.

Bali, which is known as a paradise island, can always display the image of a friendly, kind, and tolerant society. These images are then able to attract the tourists' hearts to visit Bali. This open identity of Balinese society is also what allows the 
emergence of a high tolerance for other cultures.

Geguritan Nengah Jimbaran, which is the object of this research material, is one of the manuscripts written by Cokorda Mantuk Ring Rana. Cokorda Mantuk Ring Rana used Malay in writing Geguritan Nengah Jimbaran. The use of Malay as the writing of a literary work during the colonial period was unusual for a poet, which can be interpreted that Cokorda Mantuk Ring Rana wanted to introduce a new style in Balinese literary work.

A brief reading of the Geguritan Nengah Jimbaran manuscript provides an understanding of the Badung people's life during the Cokorda Mantuk Ring Rana government period which represents the tolerance of the Balinese people who are predominantly Hindu towards the culture and ideology of people outside Bali. Cokorda Mantuk Ring Rana had many Muslim soldiers who helped him a lot during the battle of Puputan Badung against Dutch colonialism. Cokorda Mantuk Ring Rana also married a Javanese Muslim daughter who was then buried on the edge of Kepaon beach.

Cokorda Mantuk Ring Rana's idea in Geguritan Nengah Jimbaran is interesting to be studied in the discourse, especially if it is related to the intolerance problem that has happened recently. The idea as outlined in Geguritan Nengah Jimbaran is also very relevant to religious moderation which has the meaning of an attitude that believes in religious teachings that are believed and provides space for religions that are believed by others, also that in the life of plural and multicultural society such as Moderation Indonesia must be understood as a shared commitment to maintain a balance that every member of society regardless of ethnicity, culture, religion and political choice must listen to one another and learn from each other to train the ability to manage and overcome differences between communities.

Based on those explanations, some problems will be revealed in this study are
(1) what is Geguritan Nengah Jimbaran; (2) How is the religious moderation concept in Geguritan Nengah Jimbaran; and (3) How is the relevance of the religious moderation concept in Geguritan Nengah Jimbaran to the multicultural life of Balinese society right now.

\section{METHOD OF THE STUDY}

This study used a qualitative approach, which was included in the qualitative approach to the literature philosophy. Geguritan Nengah Jimbaran which was a classic literary work would be a material object in this study. Then it was analyzed using a typical philosophical method, especially to find the formula for religious moderation referred by the author of Geguritan Nengah Jimbaran, Cokorda Mantuk Ring Rana, as a formal object. The data in this study were collected through a literature study of primary data sources, those are Geguritan Nengah Jimbaran and other literature related to religious moderation. The data in the form of the Geguritan Nengah Jimbaran script were then translated into Indonesian to find out the meaning of the text. Then the data that has been collected is reduced to determine the appropriate data for analysis using the hermeneutic method. Through this hermeneutic method, the data is then analyzed through the hermeneutic stage so that the results of data analysis are expected to be truly objective data. The results of the critical analysis of the data are presented in a descriptive-narrative form.

\section{DISCUSSION}

\section{A. Knowledge about Geguritan Nengah Jimbaran}

The term geguritan in Kamus BaliIndonesia Beraksara Latin dan Bali comes from the word gurit which means transform, compose, and adapt. The word gurit has the suffix to guritan which means transformations, compositions, and adaptations. The word guritan is reduplicated into geguritan, which means an adapted story in the form of a song 
(2008: 251). Geguritan is a traditional Balinese literary work that is bound by a sound rule called pupuh. Geguritan is generally written in Balinese, but this is not the case with Cokorda Mantuk Ring Rana's geguritan.

Cokorda Mantuk Ring Rana was the King of Badung who did Puputan, an event, and an action that later attracted researchers, historians, cultural observers, and others. He did the puputan action to face the big Dutch attack at that time. However, Cokorda Mantuk Ring Rana was not only a king, but he was also an author. The literary researchers called him "Kawi Raja", "Raja Nyastra" (the writing King). His creations are Geguritan Loda, Niti Raja Sesana, Hredaya Sastra, Dharma Sesana, Nengah Jimbaran, and Purwa Sanghara. The distinctive feature of his works is that he always recites the phrase "the Surakarta way of tembang", even though it is known that all of his works were created in Bali. This indicates that readers of his works sing the works using the Surakarta style which is often used in the term Javanese song (bdk. Agastia, 2006: 1).

Cokorda Mantuk Ring Rana always inserts words of Malay in his works; even in Geguritan Nengah Jimbaran it is entirely Malay. Geguritan Nengah Jimbaran became the first geguritan in Balinese literature that uses Malay. Geguritan Nengah Jimbaran uses Pupuh Dandang (38 stanzas), Pupuh Ginanti (22 stanzas), Pupuh Pangkur (31 stanzas). Cokorda Mantuk Ring Rana in Geguritan Nengah Jimbaran told folklore by presenting himself as the character I Nengah Jimbaran who stayed in Banjar Tampakgangsul Denpasar. The folklores that he wrote were not only legends, chronicles, but also acculturation of existing cultures. As known, Geguritan Nengah Jimbaran was completely written at Puri Badung on Sunday Pahing Wuku Ugu, seventh Panglong, Kapart Month (October), Isaka year 1825 or 1903 AD.

Kapandyan, Anak Agung Istri in Creese et al., 2006: 196-197, mentioned that in the 1900s the history recorded expansions carried out by foreigners to Bali. They brought slaves from various regions in the archipelago to change the residence places wherever they landed. Meanwhile, the pluralistic distribution of the Badung kingdom society (which is now known as Denpasar), has filled the fortresses throughout the Badung Kingdom. The entire North, South, East, and West regions of the kingdom already have their mapping. They were the people who consist of family, clan, or soroh namely: Soroh Menesa, Senggu, Pande, Manik, Saunggaling, Pasek, Arya, BrahmanaBrahman, etc. People who do not have a family and live as guides (someone who works on the king's land) are placed in the area of Taman Yang Batu Village. While their Muslim community is the Bugis people who live around Dukuh, Kepaon, Serangan, or Kesiman. The Bugis who live in Kepaon is often called Duwe Pemecutan, while the Bugis who live in Serangan is often called Duwe Denpasar. The Bugis tribe has been noted to be ready to participate in defending the Badung Kingdom when there is a dangerous threat. This multicultural atmosphere built good communication that also results in harmony in society's social life. In the end, the languages used are Malay, cultural intersections also occurred as an effort to discover and create a new and harmonious culture.

This condition is described in the story of Geguritan Nengah Jimbaran, here is the story: in Banjar Tampak Gangsul, there lived a farmer named I Nengah Jimbaran. His rice field was in Yang Batu. He was a poor farmer who was sad because his wife who has married him for a while passed away because of a cholera epidemic. I Nengah Jimbaran put deep love for his wife, so he prevented Banjar members from burying his wife's body. But in the end, they gave an explanation for him which made him realize then he gave up his wife's body to be buried. I Nengah Jimbaran entertained himself in the middle of the rice 
fields, but the beautiful rice fields were not enough to comfort him so he returned to stay in his wife's grave. He was there day and night without eating, drinking, and sleeping. Love for his wife was never subsided even the stormy rain happened in the grave. Finally once midnight he heard a word from the sky which indicated that if he wanted to meet his dead wife, he had to walk towards the Northeast. Then he followed the word. He walked in confusion and finally, he arrived at a small temple. At the temple, he met an old man dressed in white. The old man was very sorry to see I Nengah Jimbaran who was very emaciated and looked very sad. So, the old man told I Nengah Jimbaran to cook some rice and a small fish to eat, strangely the rice and fish never run out.

At an enlightenment point given by the old man, I Nengah Jimbaran was told to meditate in silence near a high place. Then he met his wife, Atma, who gave him a message to let her go. The wife also advised I Nengah Jimbaran to find a wife who had been appointed by his late wife. The new wife is a good girl who is an angel with the provisions of only having one wife. I Nengah Jimbaran confirmed his wife's mandate. He returned with his new wife to Yang Batu, where he became a healer. One day, the Badung King was seriously ill, I Nengah Jimbaran tried to treat him. Unfortunately, I Nengah Jimbaran did not hear that whoever succeeded in curing the king would be awarded a beautiful woman to be a wife. I Nengah Jimbaran was surprised who succeeded in healing the king but he was also in a dilemma to decide. As his loyalty to the king, he chose the king's orders and gave up his wife, who was an angel, disappeared.

The story of I Nengah Jimbaran not only contains the love theme but also contains loyalty messages. The loyalty messages were carried out in a forward path by the character of I Nengah Jimbaran. The dialogue between the characters, in the conversation between I Nengah Jimbaran and his imaginary wife, contains multicultural teachings. As in the following quote:

Serta lagi supaya berpikir/ siang malem tyada keputusan/ memikir negri slametel daerah kota Badung/ serta jampe jajahan pinggir/ rajin-rajin mamreksa/ apa sudah betul/ apa belum kajalanen/ apa suka apa susah orang negeri/ itu supaya terang// Itu negri yang badan sendiril tyada boleh jaga dengan badan lengah/ jikalau kasihan dirine/ negri juga begitu/ tyada boleh dibuat lain/ hati sendiri jangan/ dibedakan wujud/ sama hati orang banyak/ kita susah orang lain susah lagi/ timbang dengan ikhtiar/l (Geguritan Nengah Jimbaran, Pupuh Dandang $13^{\text {th }}-14^{\text {th }}$ verses)

The quote above becomes a quote from the sentence given to I Nengah Jimbaran. The sentence [dibedakan wujud/sama hati orang banyak] indicates that different births such as being Muslim, Hindu, or other descendants in the Badung Kingdom should not be seen as a difference. The important thing here is the same heart and the same rhythm, so that loyalty grows among people. [Kita susah orang lain susah lagi/ timbang dengan ikhtiar], the humanity teachings are the ideas that I Nengah Jimbaran embraced in this text, feeling the others' suffering, having a tolerant attitude towards fellow humans to make life more peaceful by ikhtiar. The words [ikhtiar] are often heard in Muslim teachings when reminding people to pray Tahajud to be calmer and feel their true self.

Hati mesti sabar pegang adil/ mengotbahkan titahnya agama/ supaya petitis baik/ menjalani yang betul/ nyang sudah sah mufakat dari/ papreksanan aksara/ agama yang dulu/ menetapkan kelakuan/ nyang kesuhur dari orang alim adil/ yang sudah kaliwatan// (Geguritan Nengah Jimbaran, Pupuh Dandang $11^{\text {th }}$ verse)

It is really impressive when reading this stanza. The sentence is filled with 
Islamic nuances. The words [kotbah], [sah], [mufakat] are spread in this geguritan. As has been said in the previous quotation in the $13^{\text {th }}$ to $14^{\text {th }}$ verses, loyalty within oneself is spoken deeply in the geguritan verses. The loyalty doctrine is not only being faithful to others but also being faithful to ourselves. When you return to yourself, by tahajud with your mind's silence, there will be a desire to share the religious teachings. Of course, there is a question that arises, what religion the author believed, or what religion I Nengah Jimbaran followed in the text of Geguritan Nengah Jimbaran. Then who was I Nengah Jimbaran?

Description of the new ideology and theology in this Geguritan Nengah Jimbaran appeared when the authors tried to furtherly examine the content of Geguritan Nengah Jimbaran then compared it with other works of Cokorda Mantuk Ring Rana. The authors also tried to relate it with the social cognition that happened at that time. The character of I Nengah Jimbaran was most likely the description of Cokorda Mantuk Ring Rana's character itself. As a writing king, he did social contact with his society in various regions and from various ethnicities. The origin of modern thought was born here. Religion is the teaching of truth, whatever the religion's name is. But there is one thing as the main focus that is who practices the religion, and then the answer is found: humans. When humans become the main role in moving that religion, they will intersect with other humans. Of course, friction is inevitable, so Cokorda Mantuk Ring Rana captures this, that one-day pluralism will be possible to produce a conflict between humans. So Cokorda Mantuk Ring Rana tries to define diversity in his literary works.

Geguritan Nengah Jimbaran covered the diversity of thinking and the plurality of society to be a reference for thinking in the future. Multicultural life produces new cultures which later became the identity of the area and later became an inspiration for other regions. Bali has embraced humanity with humans still humans, from wherever, born from whomever they are. Humans are still humanized, differences in choices are the same as personal points of view, but as humans, they are still emphasized on the good and bad according to social construction and social norms that have become a mutual agreement. Cokorda Mantuk Ring Rana in the work of Geguritan Nengah Jimbaran managed to free himself to see all his society as human beings even though they come from various heredity backgrounds.

Ardhana, 2015:15 argues that the concept of a multicultural society is always identical to an intercultural society. This community is known as a society consisting of diverse ethnicities in various cultures. Each other is limited by the coexistence atmosphere. A modern high complex social system consists of a cultural system that is not the only one, in a closed value system, but it consists of various value patterns, for example, the influence of belief systems, ideologies, cognitive systems, and others. Cokorda Mantuk Ring Rana in the Geguritan Nengah Jimbaran indicates that the multicultural society in Bali has existed since the development of the Badung kingdom.

\section{B. Embrio of Religious Moderation in Geguritan Nengah Jimbaran}

Nyang tersebut di dalemnya tulis/ serta pahamnya supaya terang/ menuntut sebole-bole/ dari timbangan halus supaya jangan kalempit/ menimbang panjang-panjang/ perkara yang wujud/ apa yang bikin selamet/ supaya inget serta dikasihi/ hati suci dan sabar// (Geguritan Nengah Jimbaran, Pupuh Dandang $12^{\text {th }}$ verse)

The character of religious moderation requires openness, acceptance, and cooperation from each of the different groups. Therefore, every individual religious follower, regardless of ethnicity, culture, religion, and political choices must 
be willing to listen to one another and learn from each other to train the ability to manage and overcome differences in religious understanding between them (Tim Penyusun Kementerian Agama RI, 2019: 14). Pupuh Dandang's quote from the $12^{\text {th }}$ verse of Geguritan Nengah Jimbaran refers to the notion of religious moderation that has been the topic of discussion in recent times. As written in the book Moderasi Agama published by the Research and Development and Training Agency of the Ministry of Religion of the Republic of Indonesia (2019: 18), the word 'moderation' comes from Latin moderâtio, which means moderation (no advantages or disadvantages). The word also means selfcontrol (from an attitude of very strengths and weaknesses). The Big Indonesian Dictionary (KBBI) provides two meanings of the word moderation, namely: $1 . \mathrm{n}$ violence reduction, and 2 . $\mathrm{n}$ extremes avoidance. If it is said, "that person is moderate," it means that the person is being fair, ordinary, and not extreme. In English, the word 'moderation' is often used in the sense of average, core, standard, or nonaligned. In general, moderate means promoting balance in terms of beliefs, morals, and character, both when treating others as individuals, and when dealing with state institutions.

One of the basic principles in religious moderation is to always maintain a balance between two things, for example, the balance between reason and revelation, between physical and spiritual, between rights and obligations, between individual interests and communal benefit, between necessity and voluntarism, between religious texts and ijtihad of religious figures, between ideals and reality, and the balance between the past and the future. Thus, the essence of religious moderation is fair and balanced in viewing, addressing, and practicing all of the coupled concepts above. In the Big Indonesian Dictionary (KBBI), the word 'fair' means 1) impartial; 2) side with the truth, and 3) properly/not arbitrary. The word 'referee' which refers to someone who leads a competition, can be interpreted in this sense, namely someone who is not partial but is more in favor of the truth. The second principle, balance, is a term to describe a perspective, attitude, and commitment to always stand for justice, humanity, and equality. The tendency to be balanced does not mean disagreements. Those who have a balanced attitude are assertive, but not harsh because they always side with justice. It's just that their siding does not take away other people's rights to the detriment of harm. Balance can be considered as a form of perspective to do something sufficiently, not excessive, and also not less, not conservative, and also not liberal (Tim Penyusun Kementerian Agama RI, 2019:18).

Furthermore, it explained, for a plural and multicultural society like Indonesia, the perspective of religious moderation is very important so that each can dialogue diversity, both various religions, beliefs, philosophy of life, science, to various local traditions and customs. Religious moderation requires religious communities not to shut themselves in, not exclusive (closed), but inclusive (open), merging, adapting, associating with various communities, and always learning besides giving lessons. Thus, religious moderation will encourage each religious community not to be extreme and excessive in addressing diversity, including religious diversity and religious interpretation, but to always be fair and balanced so that they can live in a collective agreement. In the context of a state, this principle of moderation was also able to unite independent figures who had various head contents, various political interests, and various religions and beliefs in the early days of independence. Everyone moves to the middle to find a point to jointly accept the form of the Unitary State of the Republic of Indonesia (NKRI) as a collective agreement. The willingness to accept the Republic of Indonesia as a final form of statehood can 
be categorized as a tolerant attitude to accept the concept of a nation-state. (Tim Penyusun Kementerian Agama RI, 2019:22)

The ideal idea of Cokorda Mantuk Ring Rana as contained in the $12^{\text {th }}$ verse of Pupuh Dandang above refers to the concept of religious moderation that is being predicted by the government today to strengthen the brotherhood in Indonesia. Cokorda Mantuk Ring Rana read the direction of this nation's existence through conditions in the 1900s. Reflecting on the pluralism that existed in the Badung kingdom at that time, it was possible if tens or even hundreds of years from the time the geguritan was created, there would be a crossover of diverse cultures especially in Balinese's human life, and generally in Indonesia's human life.

As mentioned by Pierce in Ratna, 2007:268, literary works are society's mirrors. Literary works are not merely the imagination and creativity of the author, but literary work is a creation that allows showing the events behind events, events that have already been, are current events, and may occur events. Literary work resembles life, but literary work is not life itself. The literary text as a whole is a sign. The primary means of literature is language. Language as a means of communication is a sign system. Signs require an interpretation. Signs are meaningless without interpretation. The sign is whatever produces meaning. Literature requires a semiotic study to dissect the meaning expressed through language. Regarding signs and interpretations, the author wants Balinese society to maintain their identity to live together, get along with each other, and appreciate differences.

Geguritan Nengah Jimbaran as a literary work has a function both interior and exterior (bdk. Wellek, 1990: 85). The function of literature plays a role in shaping the reading community environment. Geguritan Nengah Jimbaran is full of social values and cultural norms that can be used as a guide for life. The social values and cultural norms mentioned are the essences of life experiences which then become role models in society. These values are then passed on from generation to generation as the teachings of pluralism between communities.

\section{Religious Moderation of Balinese Communities in Historical Track}

Based on the previous explanation, religious moderation can be understood as the perspective, attitude, and behavior of always taking a position in the middle, always acting fairly, and not being extreme in religion. A reduction in violence and extremes avoidance can be said as a middle ground. If then connected with the context of Geguritan Nengah Jimbaran by Cokorda Mantuk Ring Rana, moderation becomes a new thought, producing a new perspective on social life that occurred in the 1890 s to 1900s in Bali. Multicultural life, interfaith and various cultures that entered Bali produced a new perspective in living life. Bali, which is open to change, moves dynamically so that reforms occur in various aspects of life, one of which is the literary work's creation.

History records, in general, it can be said that the existence of Indonesia's cultural diversity can coexist side to side with one another from ancient times until now. The condition of Indonesia's cultural diversity is formed from a long historical journey starting from prehistoric times to the present. These diverse cultural conditions are also formed from outside cultures such as India, China, Arabic, Europe (Ardhana, 2019: 11) Geguritan Nengah Jimbaran, implicitly wrote that Puri (kingdom) is a center. The king as a leader is explained that he should protect society's rights. Puri is a system that is bound by time and space, a place for manunggaling kawula gusti, cultural symbols, government institutions, and government centers.

Bali is the epicenter of Hinduism in Indonesia, especially since the last Hindu 
kingdom which originally controlled Java and the archipelago faded away, then migrated or crossed influence with the kingdoms in Bali (Munandar, 2005). Even though long before the entry of Hindu influence from Java, Bali was inhabited by native Balinese known as Bali Aga or Bali Mula (Utama, 2015), but this track seems to have been "drowned" by the wave of "immigrants" who made Bali as it is known today. Gelgel Kingdom in Klungkung was a pioneer in embracing these "newcomers" and spreading them throughout Bali (Fadillah, 1986, 1999; Tim, 1997/1998; "Jelajah", 08 ${ }^{\text {th }}$ and $12^{\text {th }}$ Edition, 2010; $18^{\text {th }}$ Edition, 2011). Now, about 500 years later, the majority of the Hindu population in Bali has almost reached $3,247,283$ of the total population that is $3,890,757$ or $83.46 \%$ (BPS Provinsi Bali, 2010). However, other religious followers, especially Islam, still have a special place. There is seldom a big explosion due to the intersection of Hinduism and Islam. Even the Bali Bombings I in 2002 and Bali Bombings II in 2005 exploded, which many people considered to be Islamic radicalism movements, it did not immediately spark religious conflict between Hinduism and Islam. What is unique, the two religions even contemplate: "what is wrong between us?"

After those big incidents, and it has been started in the 2000s along with the rolling reforms, Balinese identity politics began to spread. The "Ajeg Bali" movement which was sponsored by the Bali Post, the most influential media group in Bali, was used as a medium to create a distinction between "you", "you", and "me", "us" but this movement began to fade. Claims of Balinese or Hinduism could be heard occasionally, but even then it was only vague. This phenomenon can be understood as a form of anxiety from the Balinese people over the erosion of Balinese culture by outside influences (Atmadja, 2010). As a result of maintaining the identity which is sometimes clear, several incidents leading to discrimination by both Hindus and Muslims have also gone viral and drawn public attention. For example, online sites had circulated, including nusabali.com about hotels in Bali that would not accept non-Hindu employees, and republika.co.id the issue of prohibiting Muslimah employees from wearing a veil. (Segara, 2019: 87).

Unlike in the past, and especially because of the different time contexts and dynamics, the relatively stable relationship of religious life between Hinduism and Islam has been indicated to be like the incident above. However, in general, the foundation of their relationship has been stronger. Even the Denpasar city as the urban center in Bali and the most heterogeneous area, when the Maarif Institute surveyed it in 2016, it got a score of 80.64 and entered the top three along with Yogyakarta and Bandung as the "The Most Islamic City" in Indonesia, beating several areas with a majority Muslim population. Freedom of religion and belief as part of the safe indicators in the Islamic City Index (IKI) shows that non-Hindu religions in Denpasar or Bali, in general, can express themselves freely in public spaces. The fluidity of these two religions cannot be separated from the history of their entry and development in Bali. Especially for Islam, its close relationship with Hinduism in Bali is a piece of the puzzle that has long been integrated into a beautiful mosaic. In historical records, the presence of Islam began in the 1400s (see Fadillah, 1986, 1999). The arrival of Islam was more dominated by commercial motives so that its distribution became sporadic because it was centered in trade centers. Most strategically in almost all coastal areas of Bali, Islam can develop well.

The construction of a multicultural society in Bali is from a long history and even colonial influences. The impact of the Dutch colonial policy in colonies between natives and foreigners such as Arabs, Chinese, and Indians was also felt in Bali. Besides, the classification of Balinese 
society itself into various groups, aristocrats, middle class, and society, in general, affects the complexity of society in Bali, especially Denpasar (as the territory of the Badung Kingdom). The migration of various ethnic groups was marked by the presence of various Javanese villages, Kepaon villages, Benoa villages, and Arab villages.

A multicultural society is formed based on the historical and migration processes, Mintzel in Ardhana, 2011: 19). The formation of a multicultural society in Bali is closely related to the formation of ethnic groups that involve the social process of exclusion and incorporation and the selection of socio-cultural aspects that are considered relevant to identity construction. The discussion of cultural issues is actually from understanding cultural construction. In this connection, culture is seen as a product of an earlier process and is open to reinterpretation to generate new ideas.

The history of migration in Bali related to the entry of Islam and Catholic Christianity in Bali. The entry of Muslimlike migrants to parts of Bali has its unique development to be aware of. Several written sources and information revealed that Muslim migrants have entered Bali since the XIV century, when the Balinese kingdom was centered in Gelgel, which is currently the territory of Klungkung Regency, during the reign of Dalem Waturenggong. The territory of the Gelgel Kingdom included Bali, Lombok, Sumbawa, and Blambangan (East Java). Muslims first came to Gelgel, Klungkung. Gelgel since XIV has been the center of government in Bali. The Muslims came as the escorts of Dalem (the title of king) from Majapahit. One source said that there were about 40 of their companions who came to Bali. They came when the Gelgel Kingdom was ruled by Dalem Ketut Ngelesir as the first Gelgel King (1380-1460). It is said that Muslims who settled in Gelgel did not establish separate kingdoms like the kingdoms on the North Coast of Java Island during the Majapahit Kingdom. They were as servants in the palace (Ardhana et al., 2011: 43-44)

However, in general, the development of Islam in Bali is mostly carried out through an assimilative process rather than expansion (see "Jelajah" Edition 18, 2011: 4-9), for example through trade and marriage. Even the arrival of Islam is said to be in steps, not in the same period (Mashad, 2016: 21). As for the entry of Islam to Klungkung and then other kingdom vassals, it was estimated that happened around 1469. It was symbolized by a delegation from Demak, which means it was also through government channels. Finally, starting from Gelgel Village or now Klungkung District, Islam spread to form communities in Lebah Village and Jawa Village in Klungkung District, Kusamba Village in Dawan District, and Toyapakah Village in Nusa Penida District (see "Jelajah" Edition 08, 2011: 4-9).

The Klungkung Kingdom was ordained as the center of the kingdoms in Bali. The first current was by agreeing with Wirawan's conclusion which he conveyed in the seminar paper "Sejarah Perkembangan Islam di Bali" (1980) by saying that Islam had entered Bali through the Gelgel Kingdom since the XIV century when Dalem Ketut Ngelesir was king (1380-1460) visited Majapahit. After returning from Java, Dalem Ketut Ngelesir brought about 40 Muslims to Bali and settled in various jobs, such as being a courtier, translators, astrologers, etc. This conclusion was a little bit "debated" by research on the Guidance and Da'wah of the Islamic Religion of Bali Province (1997/1998) which states that the entry of Islam to Bali was precisely when the Majapahit Empire collapsed, not when Dalem Ketut Ngelesir visited Majapahit when it was reaching its golden age. Even Hayam Wuruk, as the king at that time, maintained good tolerance among religious believers, especially between Hinduism and Islam, which at that time had begun to develop. The second argument that is 
strong enough to be accepted is that after the collapse of the Majapahit empire, estimated in 1400 caka or $1478 \mathrm{AD}$, Islamic kingdoms began to exist based in Demak and Mataram. When it began to grow rapidly during the Majapahit downturn, Islam spread its influence to Bali, which successively started from Klungkung as the center of Balinese government, then through vassals from the Klungkung kingdom, namely Buleleng, Mengwi (Badung), Karangasem, Badung, Tabanan, Bangli, and Payangan (Gianyar).

Meanwhile, the migration history in Badung Regency is known from Javanese, Bugis, Makasar, and Sasak ethnicities besides other ethnicities that are found to be relatively small. Migrants from Bugis lived in Tanjung Benoa Village, South Kuta District, and Badung Regency. They are Muslim and live in groups. Most of them are fishermen. Their arrival from Bugis was started by the trade relations between the Bugis and Balinese people under the Badung Kingdom since the $17^{\text {th }}$ century. This good relationship was proven when the Badung Kingdom wanted to attack the Mengwi Kingdom. The King of Badung needed a prior warrior from the Bugis people. The invasion of Mengwi was successful because of the cooperation between the Badung Kingdom troops assisted by the Bugis troops and Raden Sastraningrat and his followers from Java (Ardhana, et al. 2011: 46). So the formation of a community in each village has a different historical process. Likewise, ethnicity, culture, and religion are also different, seen from the ethnicity consisting of Balinese, Bugis, Javanese, Malay, Madurese, and Sasak. Meanwhile, the religions believed to consist of Hinduism, Islam, Christianity, Catholicism, and Buddhism.

It was different from other regions in Bali, in Banjar Tuka, Dalung Village, Kuta Utara Sub District, Badung District, there is found people who are Balinese but not Hindu like most of the Balinese, but they choose to Catholic Christian beliefs.
The presence of Catholic Christians is closely related to the entry of Catholic missions in Bali around the 1930s. The first Balinese who believed in Catholic Christianity came from Tuka, namely, I Made Bronong and I Wajan Dibloeg. He was baptized by Pastor Johanes Kersten, SVD in 1936 at Kapela Denpasar (Kersten, 1948: 210; Ardhana, et al. 2011: 47). Thus in Banjar Tuka, there are Christians, Catholics, Hindus, and some Muslims. The existing facilities in Banjar are the Banjar hall for the general public, a temple for Hindus, a church for Catholic Christians. Besides, there is also a Secondary Seminary. It is a school for educating candidates of pastors. This seminary is the only candidate of pastor's school in Bali. This multicultural life describes different ethnicities and different communities run in harmony in Banjar Tuka. If there is a problem, the religious leader forum will hold a dialogue to find a solution.

\section{The relevance of the Religious Moderation in Geguritan Nengah Jimbaran and Balinese Society Contexts}

The beautiful view of harmony shown by the multicultural society in Bali strengthens the thesis about the religions' solid collective awareness that is done from within. Islam which comes and settles in the village is adhered to by various ethnicities. However, there is a solution when the boundaries of values that previously had the potential to separate ethnicity, eventually become common property. Koetjaraningrat (1981) stated that ethnic identity as expressed in cultural unity is not something determined by outsiders, but by the ethnicity concerned as a supporter of the culture itself. That is, the ethnic problem is a matter of human unity or collectivity which is bound by awareness of cultural unity and such awareness is often reinforced by, one of which is language unity, although this is not absolute. 
Koentjaraningrat's opinion above may reaffirm that indeed "outsiders" and "new people" who will enter a relatively homogeneous area, such as Bali will quickly follow that culture, and in a relatively heterogeneous society, ethnic identity will negotiate it with that dominant culture. Inherent with this, Bruner's (1972) research also concluded that the Batak people in Sundanese might follow the dominant culture of West Java, such as language or etiquette in social interaction. As a consequence, physical culture, in this case, will be increasingly blurred. The dominant culture to be used as an adaptive tool for newcomers was also discovered by Suparlan (1985) when describing that cultural integration was something that might occur due to interactions between ethnic groups in Pontianak, Pekanbaru, and Sumenep. The question is whether cultural identity as happened in Bali is formed or built? Current postmodern thought tends to recognize that individuals in society have the "power" to build their own identity. Giddens (in Suputra, 2006) admitted that self-identity is built by the ability to perpetuate self-narrative, thereby building a continuous feeling of biographical continuity. Gramsci (1971) called conscious effort from within himself to form a new identity as an active and creative act of maneuvering because basically, humans are never passive to meet their daily needs. Apart from the above discussion, how Balinese local wisdom become a bridge between Hinduism and Islam, in line with the opinion of Poespowardojo (1986) which stated that the essential natures of local wisdom are (1) able to survive against outside culture, (2) able to accommodate elements of the outside culture, (3) able to integrate elements of the outside culture into the original culture, (4) able to control, and (5) able to provide direction for development culture. Even though it is realized, it could be in one particular context, especially when the Ajeg Bali movement received a massive injection of reform and regional autonomy in the early 2000s which seemed to "force" other people or newcomers to follow the wishes of the Balinese with what Geertz (1973) referred to the as primordial attachment. But over time, asking "you" to be the same as "us", from this "coercion" then creating horizontal conflicts never happened. Local wisdom in the form of village, kala, patra, is an adjustment based on place, time, and the situation is still strongly held by immigrants. Even today, Balinese people still consider immigrants as guests or krama tamiu that must be respected.

The emergence of the term saling seluk in Bali indicates the success of this religious moderation. Saling seluk is a refind term of those multicultural communities in Bali who marry between religions and ethnicities. Marriage is one way to strengthen the sense of brotherhood between them. The feast is celebrated together with tolerance, of course by maintaining the mandate of each other's teachings. For example, if there is a Balinese Hindu celebration, they involve other ethnic and religious people. Of course, it is commonly known that Muslims are not allowed to eat pork which is usually slaughtered by Balinese. Food for Muslims is prepared by ordering a special meal without pork which is also cooked by Muslims. Or about the Friday Prayers which are usually arranged by Pecalang (traditional village security in Bali).

\section{Nyang kitarep puji saben hari/ moga slamat trada kaputusan/ di donya akhirat baik/ selama pegang umur/ trada lupa Hyang Widhi/ mugi-mugi kabula/ dapat panjang umur/ trada nampak batal haram/ kebetulan berjumpa hati yang suci/ dan lagi hati sabar// (Geguritan Nengah Jimbaran, Pupuh Dandang bait ke-2)}

Literary works have an important role in empowering spiritual aspects by displaying ethical and aesthetic qualities, content and form, means, and messages (Ratna, 2007: 503). Geguritan as a literary 
work also has a function in the Balinese social community. Literary works serve to teach something entertainingly. The literary work produced by the author has a historical background, which means that each text was designed to fulfill a function. Literary works are created to have multifunctionality, that is, not only to entertain but also as disseminators of understanding or teachings through the values conveyed by literary works. Geguritan Nengah Jimbaran is a traditional Balinese literary work that combines elements of pluralism in the form of art literary works (geguritan) with various conventions as an introductory medium. Geguritan Nengah Jimbaran has a literary function that is very close to the community.

Truth and goodness are always part of life so that we get gifts in the form of happiness, purity, and wisdom. In each verse of Geguritan Nengah Jimbaran, there is always advisable that balances the portion of the story with the inner journeys that the characters live in. Even the quote from the second verse of Pupuh Dandang is a contemplative thing from a Cokorda Mantuk Ring Rana. Giving discourse by revealing one's weaknesses and then comparing them to life experienced now is a speech style that people loved today. Children must get an understanding of how an act is and its consequences in the future. Not only advice for a student, but there is also advice to the teacher, the intention is that teachers also imitate the teachings of the 'teacher' in Geguritan Nengah Jimbaran to always do good to others, not justify and forbid one another. Teachers here are authors, and readers are students. Humans can learn from anything, even humans can learn from this universe.

Belief in karmaphala law has shaped the character and attitude of the Balinese in guarding their actions so that they do not conflict with moral principles and virtues. Remembering every action will be rewarded good or bad so that goodness is always an action orientation. Therefore, bad actions such as crime will be avoided so that it has implications for maintaining balance in life. Actions, whether good or bad, must produce a force so that this power influences the appearance of other actions. This karmaphala principle reminds us that if one does not want to accept bad influences, one must do well according to the teachings of the scriptures and social habits. The holy books guide habits for living to create harmony.

Agastia, 1996: 3 in Supertama, 2014: 122, expressed nobility as a power within humans to produce something valuable and monumental. Power without limits is capable of turning bad things into noble and beneficial ones. The ability to create goodness and benefit requires awareness and the ability to put Budhi in the right place. Awareness in honing culture and power for development requires freedom of expression, choice, and understanding, and is ready for a change. An argument stated that if in a change, humans can master that change, then the civilization will be safe well.

Cokorda Mantuk Ring Rana captured all these conditions. He tried to separate his struggles as a writer and the king. While standing alone as an author, he has briefly released himself as a king. This can be seen when Cokorda Mantuk Ring Rana politely wrote down:

$$
\begin{aligned}
& \text { Halus-halusnya ilmu wajib/ } \\
& \text { peliharaken supaya bertambah/ itu } \\
& \text { orang sugih baik/ dapat rejeki penuh/ } \\
& \text { tyada boleh ambil pencuri/ seperti kita } \\
& \text { orang/ ketelatan bingung/ tapi kepingin } \\
& \text { rasanya/ rasa mulya kesasar katenggor } \\
& \text { iblis/ krana kasurang-surang// } \\
& \text { Geguritan Nengah Jimbaran, Pupuh } \\
& \text { Dandang bait ke-6) }
\end{aligned}
$$

Amazingly, Cokorda Mantuk Ring Rana is presented in the quote above. The tenderness of science will be away when we are not friendly with the devil and always glorify knowledge. Every teaching teaches goodness, no teaching teaches badness. The diction in the quotation above 
can deeply feel Malay Islam, words such as [rejeki], [iblis] are the equivalent structures of the Austronesian language in the Malay cluster. The Malay influence migrated by Muslims was very much felt in this Geguritan Nengah Jimbaran. Considering the massive contact, friction, and cultural assimilation that went on massively, this condition has been controlled until now. Cokorda Mantuk Ring Rana's predictions regarding the growing diversity and pluralism made Geguritan Nengah Jimbaran one of the future cultural predictions at that time. If in the $1900 \mathrm{~s}$ there was good moderation between religious communities, then why there is not now. Harmony among people is maintained to uphold the Pancasila ideology.

Parekh, 1997 (quoted by Azra, 2003: 41-42 in Pande Made Suputra, 2006: 75) regarding accommodative multiculturalism, is a plural society that has a dominant culture that makes adjustments and certain accommodations for the minorities' cultural needs and gives freedom to minorities to maintain and develop their culture. Transformative multiculturalism as stated by Jock Youn (in Piliang, 2003) emphasized the potential for open cultural exchange, norms crossover and values, boundaries fusion, and eclecticism in various social forms, political and cultural expression. Although it must also be admitted that transformative multiculturalism in Bali has not been fully successful because there is always a tug of war between traditional culture and modernity. The desire of many Balinese people to restore the past nuances through the "Ajeg Bali" movement is only one small example of how Balinese who live in the modern era simultaneously also want an exotic and authentic Bali like the image of Bali in the past. Bateson (1972) stated that facts like this are influenced by the characteristics of Balinese culture that never ends. There is always a dynamic that produces a rhythm that lives on, like a mosaic. Traditional customs and modernity will always fight so that the transformation envisioned by massive changes has never occurred, let alone changing the structures of Balinese culture.

\section{CONCLUSION}

Multicultural societies are formed based on historical and migration processes. The formation of a multicultural society in Bali is closely related to the formation of ethnic groups that involve the social process of exclusion and incorporation and the selection of sociocultural aspects that are considered relevant to identity construction. The discussion of cultural issues is inseparable from understanding cultural construction. In this connection, culture is seen as a product of an earlier process that is open to reinterpretation to generate new ideas.

The values of pluralism in the Geguritan Nengah Jimbaran text are still very relevant to be applied. Looking back to the $1900 \mathrm{~s}$, at that time Balinese (Indonesian) people had embraced moderation. The current generation is only continuing and maintaining good relations between humans even though they have different beliefs.

The entry and development of Islam in Bali did not go through the violent path, moreover expansion, besides several sources have stated that, apart from mainstream sources claiming otherwise, that was brought by Dalem Ketut Ngelesir when he visited Majapahit. Although the Gelgel Kingdom assisted by Danghyang Niratha succeeded in developing Hindu teachings communally, Bali continued to open contacts with outsiders through commerce and ports. It is not surprising that Islamic settlements in almost all areas in Bali inhabit coastal areas. The peaceful path of Islam development history in Bali has been well preserved to this day. Besides there is still intensive contact with the kingdom, it is also due to the role of the official village which administratively places them as part of the village 
administration, so that a village is generally an official environment led by a Kaling whose people are democratically elected.

If it is drawn upwards, the Regional Government of Bali Province through various programs in the harmony field has succeeded in accelerating the harmonious life between religious believers, including Hindu and Islamic relations. Programs related to the Regional Government are also held by the Office of the Ministry of Religious Affairs in Bali Province. The role of the Pakraman village is also very large because it accepts the existence of Muslims and becomes an integral part. Through the Tri Hita Karana concept, Muslims participate actively, especially in the fields of pawongan and palemahan, and even Muslims in Kampung Sindu participate in preaching customs.

In general, the acceptance of Hindus to Muslims, apart from historical factors, is also due to the responsiveness of Muslims in Bali in adapting local wisdom which, although esoterically, originates from Hindu teachings. However, in daily practice, Hinduism becomes a culture that can integrate barriers to religious differences. The local wisdom esotericism, which is done without entering the social and public spheres, ultimately becomes a shared value to create a better world. Finally, local wisdom experience total immersion in the thought realm and human beings' action, at the same time being a connector to be projected towards a multicultural society that is both accommodative and transformative.

\section{REFERENCES}

Affandi, Nurkholik. "HARMONI DALAM KERAGAMAN (Sebuah Analisis tentang Konstruksi Perdamaian Antar Umat Beragama)" dalam Jurnal Komunikasi dan Sosial Keagamaan Vol: XV, No. 1, Juni 2012. Hal: 7184
Agastia, IBG. 2006. Cokorda Mantuk Ring Rana Pemimpin Yang Nyastra. Denpasar: Yayasan Dharma Sastra.

Ardhana, I Ketut dkk. 2011. Masyarakat Multikultural Bali Tinjauan Sejarah, Migrasi, dan Integrasi. Denpasar: Pustaka Larasan.

Ardhana, I Ketut dkk. 2019. Bali dan Multikultarisme Merajut Kebhinekaan Untuk Persatuan. Denpasar: Cakra Media Utama (Anggota IKAPI Bali).

Atmadja, Bawa. 2010. Ajeg Bali: Gerakan, Identitas Kultural, dan Globalisasi. Yogyakarta: LKIS. Gramsci, Antonio. 1971. Selection from the Prison Notebooks. Q.Hoare, Q and G Nowel Smith, eds. New York: International Publishers.

Bateson, Gregory. 1972. Steps to an Ecology of Mind, Balinese Ethos.

Creese, Helen, Darma Putra, Henk Schulte Nordholt Ed. 2012. Seabad Puputan Badung Perspektif Belanda dan Bali. Denpasar: Pustaka Larasan.

Permanadeli, Risa. 2015. Dadi Wong Wadon: Representasi Sosial Perempuan Jawa di Era Modern. Yogyakarta: Pustaka Ifada.

Piliang, Yasraf Amir. 2003. "Konsep Heteronomi sebagai Strategi Kultural Otonomi Daerah Perbandingan". Jurnal Ilmu-Ilmu Budaya Poestaka, No. 6 Tahun XIV Agustus 2003.

Ratna, Nyoman Kutha. 2007. Teori, Metode, dan Teknik Penelitian Sastra dari Strukturalisme hingga Poststrukturalisme Perspektif Wacana Sastra. Yogyakarta: Pustaka Pelajar.

Segara, I Nyoman Yoga. "Pura Langgar: Representation of Hindu and Islamic Relation in Bunutin, Bangli".Proceedings of International Seminar Bali Hinduism, Tradition, and Interreligious Studies. 
Universitas Hindu Indonesia, 2018.

Page 185-191.

Supertama, I Wayan. 2014. "Wacana Sadhu

Dharma dalam Gaguritan Dalem

Sidakarya" (tesis). Denpasar:

Program Pascasarjana Universitas

Udayana.

Suputra, Pande Made. "Identitas Etnis dan Otonomi Daerah dalam Membangun Multikulturalisme di Indonesia" dalam I.B.G. Pujaastawa (ed). 2006. Wacana Antropologi Kusumanjali untuk Drs. I Wayan Geriya. Denpasar: Pustaka Larasan.

Tim Penyusun Kementerian Agama RI. 2019. Moderasi Beragama. Jakarta: Badan Litbang dan Diklat Kementerian Agama RI.

Wellek, Rene \& Austin Warren. 1990. Teori Kesusastraan (Terj. Melani Budianta). Jakarta: PT Gramedia. 